\title{
The double danger of English as a global language
}

\author{
JEFFREY GIL
}

\section{Why Australia still needs to learn Asian languages}

\section{Introduction}

Language learning in Australia has at times been a much debated and somewhat controversial topic. A new episode in this debate began recently with the publication of a report entitled Building an Asia-Literate Australia: An Australian Strategy for Asian Language Proficiency, which argues for a significant expansion and intensification of the learning of Asian languages and cultures at all levels of education. Much of the reaction to this report has focused on the role of English as the global language and its implications for language education. The main argument made against the report's proposals can be summarised as the "English is the global language' view, a position which claims that because English is the global language, there is no need for Australia to implement a large-scale Asian languages and cultures education programme. This paper aims to refute this argument. Drawing on a range of theoretical and empirical work, it demonstrates that there is a double danger in the 'English is the global language' view as it both exaggerates the current number of speakers and extent of use of English in Asia, and misinterprets the likely outcomes of any further spread of English.

\section{The Report}

Building an Asia-Literate Australia: An Australian Strategy for Asian Language Proficiency, complied by Griffith University's Griffith Asia Institute, advocates the learning and teaching of a range of Asian languages, primarily Indonesian, Japanese and Chinese (Mandarin), but also others such as Hindi, Korean, Arabic, Vietnamese, Thai, Farsi, Bengali, Cambodian, Lao and Burmese, at all levels of education in
Australia. The report argues that given the growing economic and political importance of the Asia region, and Australia's increasing involvement with it, proficiency in these languages and knowledge of the cultures associated with them will be essential for Australia's prosperity in the future. Accordingly, Australia will need to implement an Asian languages and cultures education programme which will result in more than half of the country's population being able to speak an Asian language and some two thirds of those under 40 years of age having at least basic proficiency in an Asian language within 30 years (Griffith Asia Institute, 2009).

The report outlines five key principles for accomplishing this aim:

Principle 1: Implement a comprehensive, nation-wide, long-term strategy

Principle 2: Teach Asian languages and cultures at all levels of education

Principle 3: Build gradually with quality

Principle 4: Build and maintain student demand for Asian languages education

Principle 5: Build an adequate supply of worldclass Asian languages teachers and resources

(Griffith Asia Institute, 2009:10)

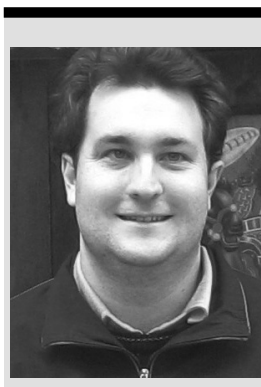

JEFFREY GIL (PhD) is a Lecturer in ESOL/TESOL at Flinders University, Australia, where he is involved in the development, teaching and administration of ESL and TESOL topics. He has also taught at university level in China. His research interests include English as a global language and China's minority languages and cultures.Email: Jeffrey.Gil@flinders.edu.au 
In brief, Principle 1 calls for coordination of policy across federal, state and territory governments, a guarantee of funding for the life of the programme, a campaign to raise public awareness of the need for Asian languages and cultures learning, and the establishment of a National Asian Languages Institute to guide the implementation of the programme. Principle 2 proposes that Asian languages and cultures be taught continuously from preparatory through to tertiary education with coordinated curricula supported by research into language teaching. Principle 3 specifies that the programme will focus initially on teaching Indonesian, Chinese and Japanese - the languages of Australia's nearest neighbour and biggest trading partners - in a small number of schools, before eventually expanding both the number of languages taught and the number of schools teaching them. Principle 4 and Principle 5 centre on students and teachers respectively. In order to encourage students to take up and persist with Asian language learning throughout their education, the report recommends various incentives and rewards be offered, and courses be tailored to students in light of their differing levels of proficiency and specific needs. Asian language courses should also include motivating and enjoyable experiences such as in-country study. Similarly, incentives such as scholarships and opportunities for further training should be used to make a career as an Asian language teacher more attractive. Principle 5 also recommends teacher training integrate the acquisition of high level language proficiency and pedagogical skills for teaching Asian languages. Incountry study is identified as a key aspect of such training, while a number of steps for ensuring sufficient teaching resources and equipment are also outlined, such as the establishment of a national online collection of teaching materials (Griffith Asia Institute, 2009). The estimated cost of the proposals made in Building an Asia-Literate Australia: An Australian Strategy for Asian Language Proficiency is AU\$11.3 billion over 30 years (Griffith Asia Institute, 2009).

\section{The reaction}

This is indeed an ambitious plan and it is not surprising that it has sparked much debate, including numerous articles, opinion pieces and letters in newspapers and on websites.
While there has certainly been some support, the report has been criticised on a number of grounds including, for example, the difficulty of learning Asian languages, the costs of the proposals, and the practicalities of implementing them (for a variety of views see Clyne, 2009; Godwin, 2009; Lindsey, 2009; Sussex, 2009). As mentioned above, however, a key argument put forward by those opposed to a broad Asian languages and cultures education programme is that because English is the global language, Australians do not need to learn Asian languages and cultures on such a scale.

English undoubtedly occupies a unique position in today's world as the global language. It has spread over a considerable geographical area and is widely used for economic, political and cultural functions. English is, for example, the working language of numerous international organisations, international corporations and academic conferences; the main language of the world's books and newspapers; and the foremost language of movies, television programmes and popular music (Crystal, 1998; Jenkins, 2007; McArthur, 2001; Romaine, 2006). Knowledge of English is therefore a highly valuable skill on both a national and individual level. According to the 2006 Australian census, 15,581,325 people, or more than three quarters of those surveyed, spoke English at home, while only 561,413 people reported that they could not speak English well or at all (Australian Bureau of Statistics, 2007a, 2007b). Such a large population fluent in English obviously benefits Australia in many of its interactions with the world. On the surface, then, the 'English is the global language' view may appear to be reasonable. However, a more nuanced examination of the role of English in Asia suggests there is a double danger in the notion that it is sufficient for Australians to use only English in their dealings with Asian nations.

\section{Exaggerating the use of English in Asia}

Proponents of the 'English is the global language' view often point out that there are many millions of people learning English in almost every country in Asia, to support their argument that Australians do not need to learn Asian languages and cultures to the extent proposed in the Griffith Asia Institute report (see 
for example Slattery, 2009a, 2009b, 2009c). Given the size of Asia's population, and the fact that English is a compulsory school subject in much of the region, there are indeed huge numbers of people studying English. This argument, however, ignores the very significant difference between an English language learner and an English language speaker. It is not uncommon that students finish their education with limited ability to use English in real life situations. China offers an example of this. After reviewing a number of studies and surveys, Yang (2006) concludes that a significant proportion of Chinese high school and university graduates cannot communicate effectively in English. To claim that the millions of Chinese students learning English make 'China the second largest English-speaking nation after the US' (Slattery, 2009b) therefore greatly exaggerates the current nature of English proficiency within China. Suggestions that China will become 'an English-speaking power' (Slattery, 2009a) or 'one of the biggest Anglophone nations' (Slattery, 2009c) are likewise rather dubious.

Similar examples can be found in other Asian countries. In South Korea for instance, evaluations of proficiency based on a variety of national and international measures often find that levels of English are inadequate to enable genuine use of the language (Plumlee, n.d.), while Martin (2004: 50) notes that in Japan 'it is rare to find a Japanese student who, after six years of English, is able to engage in even a marginal dialogue with a speaker of English'. Former British and American colonies are the possible exceptions to this trend; however, Nunan (2003:608) reminds us that '[e]ven in Hong Kong, where, on paper at least, there is considerably more English than in most other countries in the region, many students leave high school with only the most limited ability to communicate in the language'. Much of this can be attributed to education systems which place far greater emphasis on formal learning of grammar rules and passing examinations than developing communicative ability. Many of those who have received English language education in Asian countries are consequently best regarded as learners rather than speakers of the language (Yang, 2006).

This is not to say that there are no proficient speakers of English in Asia, but rather to emphasise that the number of such speakers is currently small. Based on available data, and personal knowledge of many of the countries where the languages covered by the Griffith Asia Institute report are spoken, Bolton (2008) (ET94) provides estimates of the percentage of the population with at least functional proficiency in English: 5\% for Bangladesh, Indonesia, Vietnam, Burma, Cambodia and Laos; 10\% for Thailand, South Korea and Taiwan; 11\% for Pakistan; 20\% for Japan; 25\% for China (which Bolton says is a high estimate); $30 \%$ for India; 45\% for Hong Kong and 50\% for Singapore. While such estimates can only give rough indications, the common pattern across these countries is that the percentage of proficient English speakers is low, and even in places such as Hong Kong and Singapore the majority of the population lack functional proficiency in English. It would accordingly be unwise for Australia to rely solely on English when interacting with Asia.

Turning to the uses of English: apart from in former British and American colonies where English has a long history of intranational use, the use of English within Asian countries is still relatively limited. In the debate on Asian language learning in Australia, much attention has focused on the use of English in the business domain. Slattery (2009c) says that '[w] hile there may be compelling reasons for an Australian to learn an Asian language, there are no compelling economic reasons' because '[b]y 2015, if not before, business in our region will be done in English'. Empirical studies of the use of English in business, however, cast doubt on these assumptions. A survey conducted by Pang et al. (2002) of 360 business professionals working in international trading corporations, investment companies, banks and joint ventures in five cities in China's Zhejiang province found that English was used for fax and email communication and that some contracts were written in English, but only a limited number of people were involved in this sort of work, while most used English purely for filling in forms, usually with only figures, single words or phrases, and reading specialist literature. Business professionals' levels of proficiency were also not high, with only $13 \%$ of those surveyed claiming to have very good English, 60\% claiming to have satisfactory English, 21\% claiming to have poor English and 6\% very poor English (Pang et al., 2002). These results are particularly telling as Zhejiang is a well-developed coastal province heavily involved in foreign trade. 
Chew's (2005) investigation of the language use of new graduate employees in four Hong Kong banks shows that the vast majority of oral communication took place in Cantonese, while English was used for some forms of written communication such as compiling minutes of meetings, memos, faxes and letters, and reading materials such as manuals, reviews and reports. Most of the participants rated themselves as average in reading and writing: almost two-thirds said they experienced difficulties carrying out their work due to English language demands and almost three-quarters expressed interest in training in oral skills. Chew's (2005: 434) conclusion is that the number of people who are fluent in both Cantonese and English is below the level allowing maximum productivity in these financial institutions'. In a similar case, Plumlee (n.d.) reports that foreign companies operating in South Korea frequently cite the Korean workforce's low levels of English as a key obstacle to conducting business in Korea. It is therefore unlikely Australia's business needs will be met through English alone at the present time or in the near future, thus reinforcing the need for learning a variety of Asian languages and cultures.

It is also important to consider who has access to English language learning in Asian countries. Fishman (2000) reminds us that opportunities to learn and use English are determined by factors such as social class, age, gender and occupation. Indeed, Nunan's (2003) analysis of English language education in China, Hong Kong, Japan, South Korea, Malaysia, Taiwan and Vietnam found that level of income, and residence in a rural or urban area, played a significant role in the quantity and quality of English language education students received. This raises questions about who Australians can communicate with in English, and whether these speakers are truly representative of their country's populations. In order to successfully interact with anyone outside a small elite proficient in English, Australia will instead have to use the national and regional languages in which much of Asia's population operate.

Given the present number of speakers, the extent of use of English, and issues of access to English language education in Asian countries, Australia will need to build competency in Asian languages and cultures in significant numbers across many sections of society to effectively pursue its interests with Asia on all levels and across all domains.

\section{Misinterpreting the consequences of the further spread of English}

The current situation of English is, of course, open to change. Many countries in Asia are attempting to reform English language education to concentrate on developing students' communicative ability through measures such as the introduction of new curricula, textbooks, teaching materials and teacher training programmes (see Kam \& Wong, 2004 for details of several Asian nations). There is also some evidence to suggest the range and number of functions of English within Asian societies has expanded in recent times (see for example Gil, 2005, 2008 for a discussion of English in China). If the improvement of English language education is successful and the expansion of English within Asian countries continues, it could increase levels of proficiency across the region and eventually result in English becoming a common, everyday ability, akin to numeracy, literacy and computer skills, or what Graddol (2006:15) terms 'a near-universal basic skill'. What, however, will be the consequences of such widespread proficiency in English for Australia?

Once the ability to speak English becomes so common, its value will inevitably decline. Graddol (2006:122) aptly explains that:

as English becomes more generally available, little or no competitive advantage is gained by adopting it. Rather, it has become a new baseline: without English you are not even in the race.

As explained earlier, Australia is fortunate that its large English-speaking population guarantees it a start in the race, but this does not guarantee that Australia will win the race, or even be competitive over the full distance. The competitive advantage will rest instead with those who speak English in addition to at least one other language. This is an important point, as many people in Asia are already bi/multidialectal or bi/multilingual. For example, most of China's population speaks more than one variety of Chinese, and members of its ethnic minorities commonly speak one or more variety of Chinese in addition to their minority language (Chen, 1999; Zhou, 2003). In Central Asia, it is common for people to speak the 
language of their own nation, the language of a neighbouring Central Asian nation and Russian (Schlyter, 2003, 2004). Adding English to their existing linguistic repertoires will allow such bi/multilingual people to compete for any employment or other opportunity for which English is a requirement, as well as those for which proficiency in other languages is a requirement. Monolingual English-speakers on the other hand will not be able to do the same (Graddol, 2006). This is disturbing news for anyone who believes that 'English will suffice' for Australia to remain 'a rich nation' (Slattery, 2009c).

To avoid being left behind, Australia will need to seriously study Asian languages and cultures to ensure that $\mathrm{bi} /$ multilingualism is at least as common and mainstream here as it is in other parts of the world, and this in turn will mean instituting a large-scale Asian languages and cultures programme.

\section{Conclusion}

Crystal (1998) warns that one of the potential negative consequences of a global language is that native English-speakers may believe that learning other languages is simply unnecessary. This linguistic complacency has seemingly pervaded public discussion of Asian language learning in Australia, as demonstrated by those who argue the global status of English means Australia does not need to enact a large-scale Asian languages and cultures programme. As this paper has shown, this view is flawed, and raises the possibility that Australia will succumb to the double danger of misunderstanding the current situation of English in Asia, and failing to properly consider the consequences of the further spread of the language. While there are surely challenges involved in Asian languages and cultures education, the fact that English is the global language does not excuse Australia from facing them.

\section{References}

Australian Bureau of Statistics. 2007a. 'Languages spoken at home by sex.' Online at <http://www. abs.gov.au/AUSSTATS/abs@.nsf/Latestproducts/02 60B4B1CD4563A6CA25729E0008A883? opendocument $>$ (Accessed October 26, 2009).

—. 2007b. 'Proficiency in spoken English/language by age for time series.' Online at < http://www.abs. gov.au/AUSSTATS/abs@.nsf/Latestproducts/
64A56731DA626A9FCA25729E00008A8A87D? opendocument $>$ (Accessed October 26, 2009).

Bolton, K. 2008. 'English in Asia, Asian Englishes, and the issue of proficiency.' English Today, 24(2), 3-12.

Chen, P. 1999. Modern Chinese: History and Sociolinguistics. Cambridge: University Press.

Chew, S. K. 2005. 'An investigation of the English language skills used by new entrants in banks in Hong Kong.' English for Specific Purposes, 24(4), 423-35.

Clyne, M. 2009. 'What a lode of language.' The Australian, August, 19. Online at <http://www. theaustralian.com.au/higher-education/opinionanalysis/what-a-lode-of-language/story-e6frgcko1225763498883> (Accessed August 19, 2009).

Crystal, D. 1998. English as a Global Language (Canto edition). Cambridge: University Press.

Fishman, J. A. 2000. 'The new linguistic order.' In P. O’Meara, H. D. Mehlinger \& M. Krain (eds), Globalization and the Challenges of a New Century: A Reader. Bloomington and Indianapolis: Indiana University Press, pp. 435-42.

Gil, J. 2005. 'English in China: The impact of the global language on China's language situation.' Unpublished Doctoral dissertation. Brisbane: Griffith University.

—. 2008. 'China's English language environment.' English Language Teaching, 1(1), 3-9.

Godwin, A. 2009. 'The dynamic of need.' The Australian, July, 15. Online at <http://www. theaustralian.com.au/news/the-dynamic-of-need/ story-0-1225750118050 > (Accessed July 15, 2009).

Graddol, D. 2006. English Next: Why Global English May Mean the End of 'English as a Foreign Language'. London: British Council.

Griffith Asia Institute. 2009. Building an Asia-Literate Australia: An Australian Strategy for Asian Language Proficiency. Online at <http://www.griffith.edu. au/_data/assets/pdf_file/0006/143628/buildingasia-literate-brochure.pdf $>$ (Accessed June 3, 2009).

Jenkins, J. 2007. 'Global English and the teaching of pronunciation.' Online at <http://www. teachingenglish.org.uk/think/pron/global_english. shttml> (Accessed April 17, 2007).

Kam, H. W. \& Wong, R. Y. L. (eds) 2004. English Language Teaching in East Asia Today: Changing Policies and Practices. Singapore: Eastern Universities Press.

Lindsey, T. 2009. 'Learn the lingo to earn from Asia'. The Australian, August, 26. Online at <http://www. theaustralian.com.au/higher-education/opinionanalysis/learn-the-lingo-to-earn-from-asia/story-e6f rgclo-1225766141055> (Accessed August 26, 2009).

Martin, A. 2004. 'The "katakana effect" and teaching English in Japan.' English Today, 20(1), 50-5.

McArthur, T. 2001. 'World English(es), world dictionaries.' In B. Moore (ed.), Who's Centric Now? The Present State of Post-Colonial Englishes. Melbourne: Oxford University Press, pp. 1-22.

Nunan, D. 2003. 'The impact of English as a global language on educational policies and practices in 
the Asia-Pacific region.' TESOL Quarterly, 37(4), 589-613.

Pang, J., Zhou, X. \& Fu, Z. 2002. 'English for international trade: China enters the WTO.' World Englishes, 21(2), 201-16.

Plumlee, M. K. (n.d.) 'Lingua franca or language of domination? Implications of the two faces of English.' Online at <http://maincc.hufs.ac.kr/ lri/contents/lal/32-07.pdf > (Accessed October 2, 2009).

Romaine, S. 2006. 'Global English: From island tongue to world language.' In A. van Kemenade \& B. Los (eds), The Handbook of the History of English. Malden: Blackwell Publishing, pp. 589-608.

Schlyter, B. N. 2003. 'Sociolinguistic changes in transformed Central Asian societies.' In J. Maurais \& M. A. Morris (eds), Languages in a Globalising World. Cambridge: University Press, pp. 157-87.

—. 2004. 'Changing language loyalties in Central Asia'. In T. K. Bhatia \& W. C. Ritchie (eds), The Handbook of Bilingualism. Malden: Blackwell Publishing, pp. 808-34.

Slattery, L. 2009a. 'Don't start with Asian tongues.' The Australian, June, 17. Online at <http://www. theaustralian.com.au/news/dont-start-with-asiantongues/story-0-1225736507046l > (Accessed June 17, 2009).

—. 2009b. 'Mass Asian language program is not sensible.' The Australian, July, 1. Online at <http://www.theaustralian.com.au/news/massasian-language-program-is-not-sensible/story-0-122 $5744385275>$ (Accessed July 1, 2009).

—. 2009c. 'Doomed never to peak in tongues.' The Australian, July, 4. Online at < http://www. theaustralian.com.au/news/doomed-never-to-peakin-tongues/story-0-1225745602565> (Accessed July 4, 2009).

Sussex, R. 2009. 'Don't say no to a new idiom'. The Australian, July, 22. Online at <http://www. theaustralian.com.au/news/dont-say-no-to-a-newidiom/story-0-1225752927625> (Accessed July 22, 2009).

Yang, J. 2006. 'Learners and users of English in China.' English Today, 22(2), 3-10.

Zhou, M. 2003. Multilingualism in China: The Politics of Writing Reforms for Minority Languages 1949-2002. Berlin: Mouton de Gruyter.

\section{Now available at Cambridge Journals online}

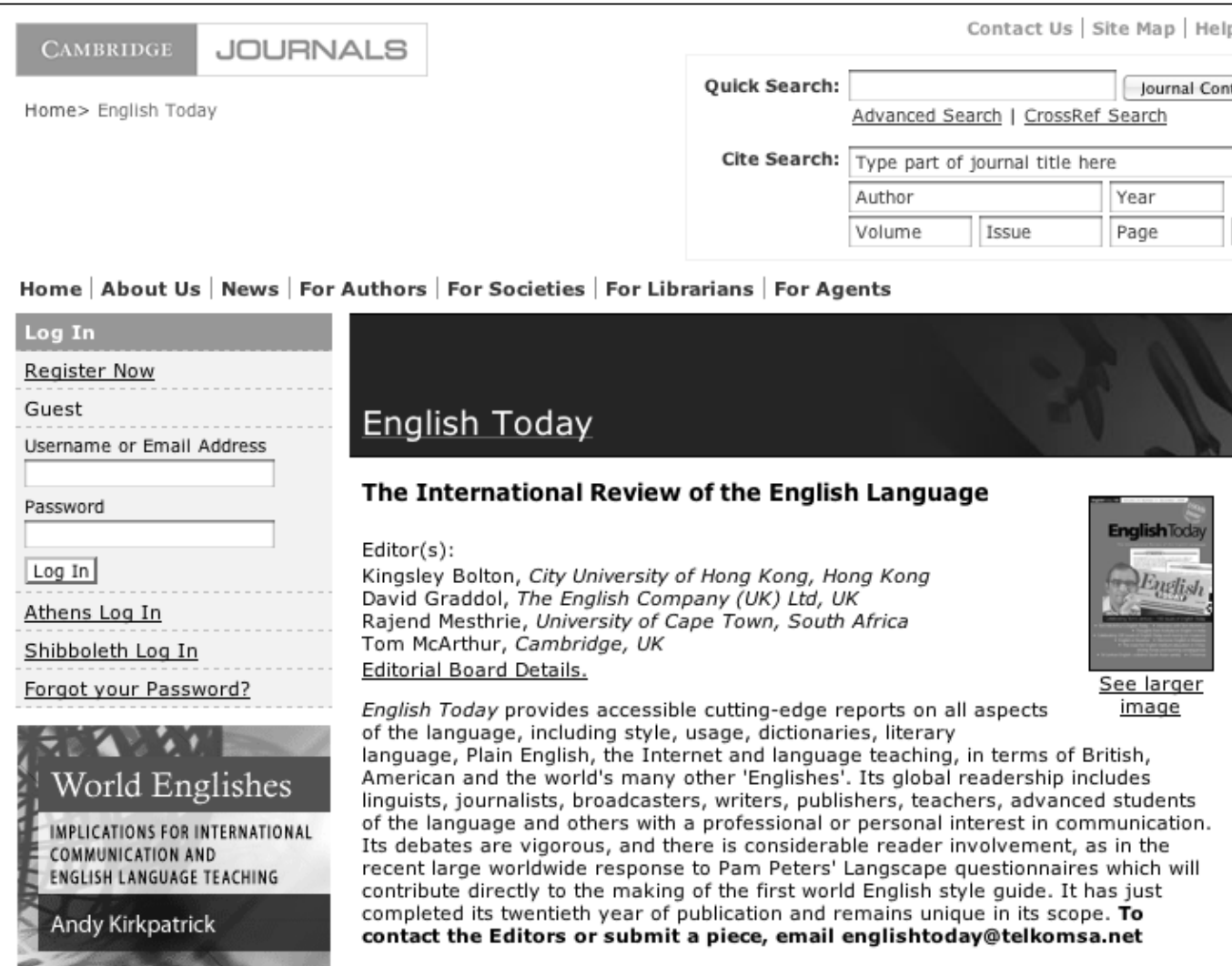

